\title{
特集
}

\section{ポリエステル長繊維糸条の物理改質 加熱加工，エアジェット加工技術}

松本 三男

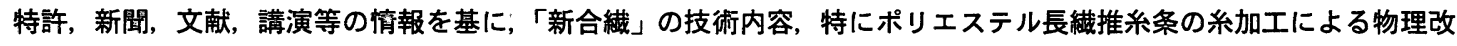
質について述べる.

\section{1.はじめに}

自然が作り出した天然瀻維の構造は複雑極まりな いが，そこに感性が秘められているように思われ る. 従って，単純な構造の合成繊維でそれを再現す るには極めて高次元の加工技術を必要とする.

幸い，含成繊維は人間が作り出したものなので, その構造や性質などは良く承知しており, 従来から 比較的自由に様々な加工を加えてきた。 その加工技 術の蓄積は今や 50 ～60年にも及ぶ。特にここ10年間 の日本の「新合繊」技術は世界から脚光を浴びるほ ど高度化してきている.

しかしながら，それらの技術内容となると，合繊 メ一カー間の過当競争の中で，公開されることはま ずない.

従って, ここでは特許, 新聞, 文献, 講演等の情 報から，筆者の浅い知識之経験に基づき，偏見が入 るのを承知の上で述べざるを得ない．

また，上記加工技術は，ポリマーから紡糸・延伸， 糸加工，製織・製編，染色・仕上げ，縫製といった ところまで幅広く及んでいるが，本稿は本特集の分 担に従って，主にポリエステル長緎維糸条の糸加工 による物理改質について述べる.

\section{2. 物理改質のための糸加工技術}

長繊維系条の糸加工技術というと，昔加ら表 1 に 示すような技術がよく知られている.
しかし，実際によく利用されているのはこのうち の仮撚加工とェアジェット加工技術である。これら は技術のポテンシャルが高い上，改良が重ねられて いて, メンテナンス, 性能 / コスト, 設置台数など の面でも有利なため，利用が集中しているものと思 われる.

従って，以下では，この仮撚加工とェアジェット 加工をべースにした物理改質技術について主に述べ る.

\section{1 仮撚加工技術}

古くから最も実績のある技術で，洗練された高性 能の加工機が何機種も競って市販されている.

新機種の例として, 図 1 に'97OTEMAS に出展 された 2 つのタイプの仮撚機を示す.

図 $1(1)^{1)}$ は撚掛装置がフリクションディスクタイ プ, 図 $1(2)^{2}$ はニップベルトタイプのあのである. 今 のところディスクタイプが主流であるが, 最近はべ ルトタイプも, ベルトのニップ圧が自動制御された りして糸質が安定し, 台数が増えてきているように 聞く，使いこなせようになれば，ベルトタイプ独自 の加工糸も出てこよう.

一方, 図 1(1)の仮撚機は，速度性能の割に従来機 種よりヒーター長が短くなっており，その分設備が コンパクトにできている. いわゆる高温ヒーターを 採用したもので，ここ数年増えてきており，これか らヒーターの主流になる可能性がある. 


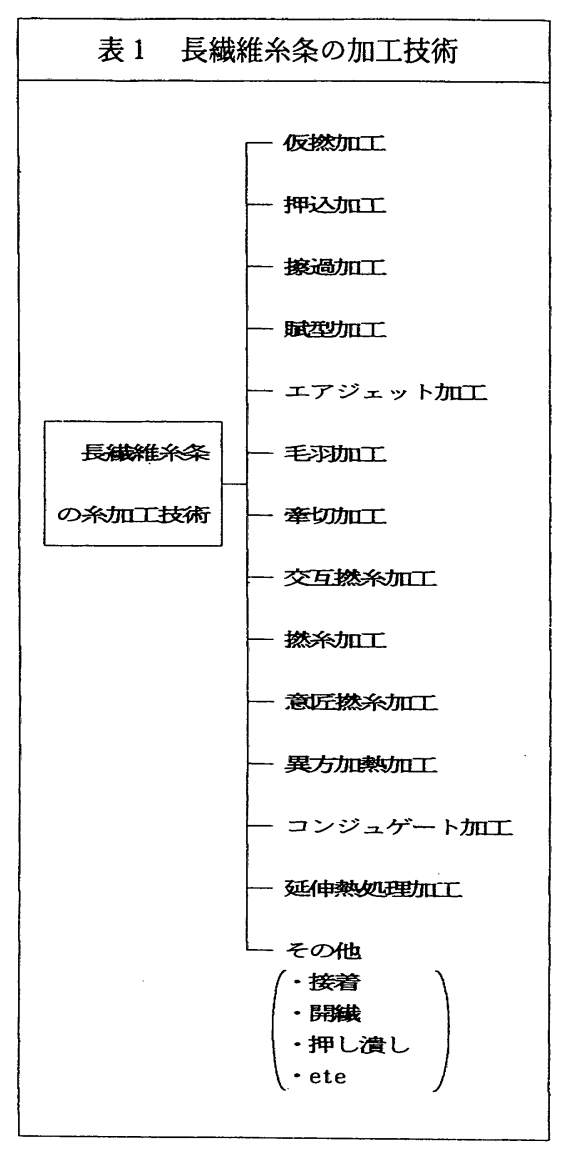

また最高加工速度は, 図 $2^{3)} に そ の$ 変遷を示すが 現在のところ1000 1500/min 位でやや伸び悩んで おり，むしろ系質管理や作業効率化面が進展してき ている，すなわち，トータル的なコスト低減技術と して, 速度以外の要素も重視され出したものと思わ れる.

ただ日本においては, 一時はポリエステル長織維 の約70\%が仮撚加工されていて，今はそれがその 1/2〜1/3に減ってしまったことからあわかるよう に，むはや市販仮撚機そのままの仕様では競争にな らず，使う側が自らブロセスに工夫を加え，特化さ れた原系を使い, レベルの高い特化加工系を生産し なければならなくなっている.

図 3 に，その特化プロセスの例を示す4). また, こ れらの特化プロセスによって造られた様々な加工糸 の捲縮および糸形態を図 $4^{5)}$, その断面を図 5 に, そ れぞれモデル的に示した.

これらは，個々に眺めると格別新しいあのではな

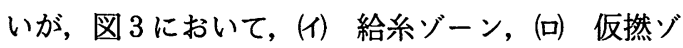
ーン, (4) 再熱セット・巻取ゾーン等の各種プロセ
スをそれぞれ組み合わせるとそれだけでかなりの数 の新プロセスが形成でき，かつ，これに本特集の前 半で解説されたような原糸の種類や加工条件を組み 合わせると膨大な種類の特化加工糸を造り出すこと ができる.こんな中で, 原糸, プロセス, 加工条件 の各特性がうまく結び付くと, 従来の商品群とは違 った，天然繊維にもないような新しい質感を持った 感性の高い商品が生まれることがある，いわゆる新 合織6)である。

仮撚技術による新合絨は，いわゆる「ニュ一梳 毛」》)を心に,「ニューリネン」,「薄起毛」などの 商品分野に主として展開されている，以下，商品分 野ごとに, 原糸, プロセス, 加工条件等の結び付き について, その推定技術を述べる.

(1) ニュー梳毛

(a) 軽量保温：例えば，図 3(1)-(2)プロセスを使用 して伸度差原糸を複合し, 図 4-(8), 図 5-(3)の系構造 を得る方法が約 20 年以上前から知られているが, こ の伸度差を大きくしてやると高性む大きくすること ができる，最近は，図6に示すようにいろいろな紡 糸速度 (伸度) の原糸が利用できるようになり, 仮 撚機をあまり改造せずとあ嵩性を容易に設定できる ようになってきている. 従って最近の新合緎は, さ らにこれに中空断面 (図 7 参照), 蓄熱材練込, 高収 縮等の特化原糸を活用してその効果を強化し, 差別 化を強めている．あちろんこれには，断面変形対策 (図 5(2)参照)，芯䩗のスリップおよび染着差対策, 対摩擦およびピリング対策等, 細心の注意が必要で ある.

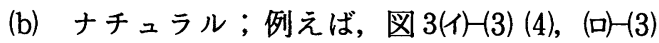
(5)，-(1)(2)等のプロセスを利用すると形態的あるい は色相的本均斉によるナチュラル感が付与できる が，低配向の原糸を扱う技術があると，複合仮撚の 際に䩗系を自然延伸倍率以下で加工するだけで簡単 にナチュラル感を付与することができる.（図 8 参 照) .

また，ポリマーにポリエステルと非相溶の有機化 合物等を混ぜておき9 ，これに仮撚加工による断面 変形歪 (図 5(4)) と, アルカリまたはアミン処理によ る分解作用等を施してやると，繊維にフィブリル10) 化が生じ，二ュー梳毛ばかりかレーヨン調にあ使え るような本格的なナチュラルタッチと外観が付与で きる(図 9 参照 $\left.{ }^{11}\right)$.

ただし，このように原糸の配向や組成まで変更し たりすると，糸加工プロセスや加工条件だけでは止 


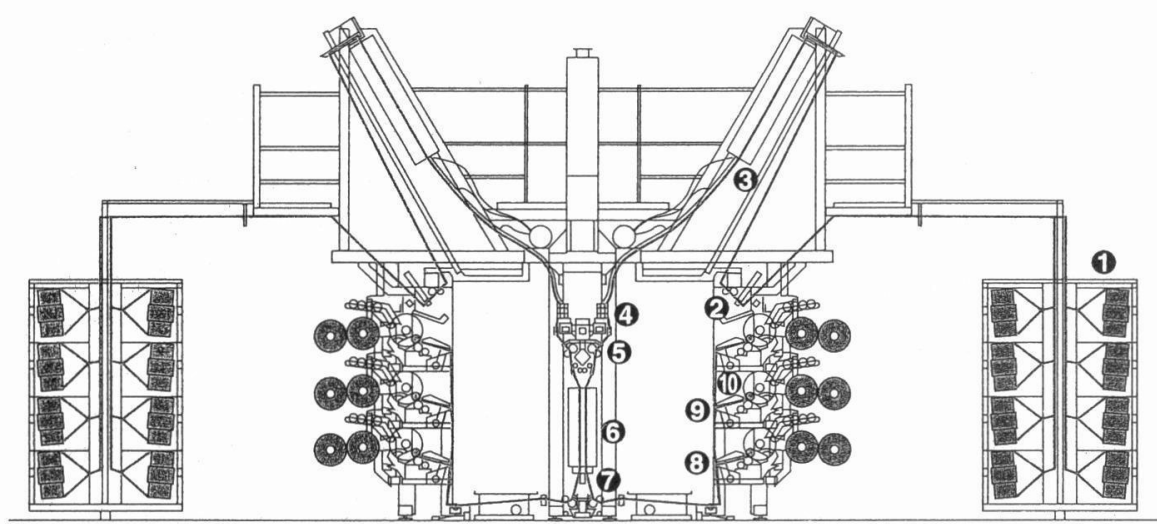

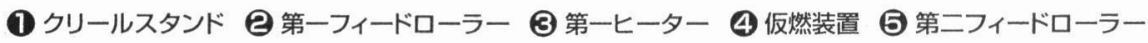
6 第二ヒーター 8 第三フィードローラー 8 オイリングローラー 9 IAD (10) 巻取装置

(1) 帝人製機 $[\mathrm{HTS}-15 \mathrm{~V}\lrcorner$ '1)
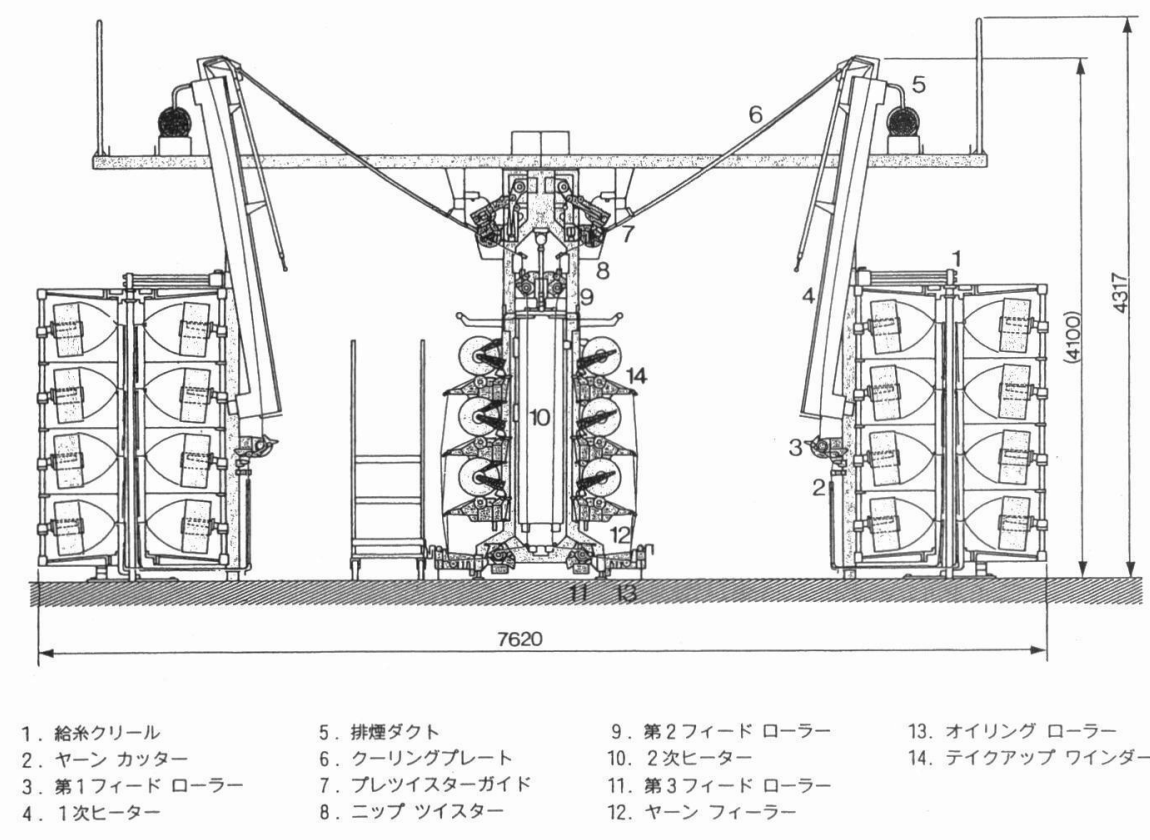

(2) 村田機械 $\left\ulcorner\right.$ Mach Crimper No. $33 \mathrm{H}_{\lrcorner}^{2)}$

困 1 最新仮撚機の例

まらず，織編染加工に至るまで細心の注意が必要に なり，かつ製品物性の実用性についても十分なチェ ックが必要になる。

(c) 色彩；例えば，図 3(イ) (1) (2) (3) (4) (5), (口) (3) (4) (6), (メ) (1) (2)等のプロセスを利用して, カチ オン可染系, 濃染系, 淡染系, シック \&シン糸, 原 着系, 系染糸, 他素材 (ナイロン, レーヨン, etc.) 等を適当に複合してやるといろいろな色彩効果が得
られるが,この際, 図 4(9), (10), (11), 等の複合構造を 選定してやると，それぞれ本調，へザー調，シック \&シン (ファンシー) 調等の色彩効果を得ることが できる.

また, 複合仮撚等で, 鞘系を低配向に加工したり, 易染原糸を利用したりすると濃染効果が得られ, ブ ラックフォーマル分野などに利用される。 また常圧 可染糸を利用したりすると, ウールやアセテートな 


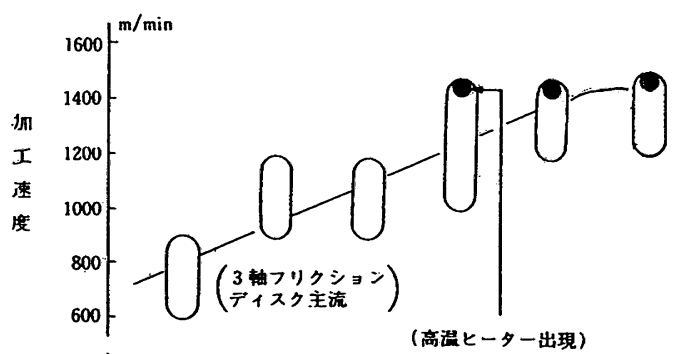

\begin{tabular}{|c|c|c|c|c|}
\hline \multicolumn{2}{|c|}{ 分類 } & 系形態 & 特徵 & 加工法 \\
\hline $\begin{array}{l}\text { 単 } \\
\text { 緎 } \\
\text { 維 } \\
\text { 荊 } \\
\text { 態 }\end{array}$ & & (1) (1) (2) & $\begin{array}{l}\text { ストレッチ、バルキー } \\
\text { 平滑、唡立、綝 } \\
\text { 四怘、价キュラー眵 }\end{array}$ & 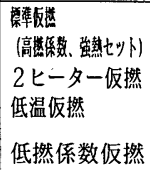 \\
\hline & 単 & $\begin{array}{l}\text { (4) } \\
\text { ( } 5 \text { ) } \\
\text { ( } 6 \text { ( ) } \\
\text { ( } 7 \text { ) }\end{array}$ & $\begin{array}{l}\text { 均斉槁性 } \\
\text { 太細嵩性 } \\
\text { 虽然謂、スラフ調 } \\
\text { シャリ感、清㴦感 }\end{array}$ & $\begin{array}{l}\text { 標準仮撚 } \\
\text { 未解撚仮撚 } \\
\text { 先撚仮撚 } \\
\text { 交互撚仮撚 } \\
\text { 融着仮撚 }\end{array}$ \\
\hline 形 & 系 & 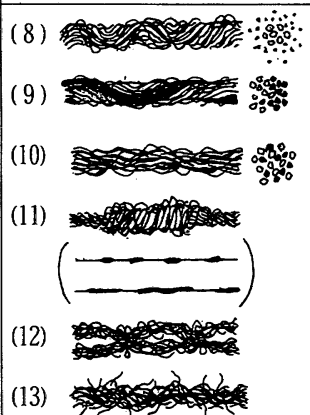 & 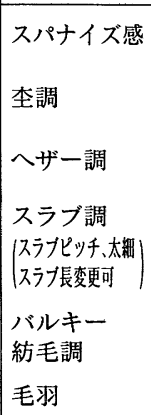 & 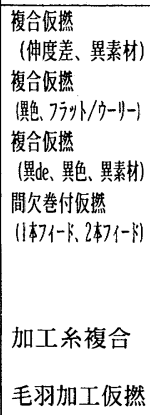 \\
\hline
\end{tabular}

図 4 各種仮撚加工糸の糸形態)

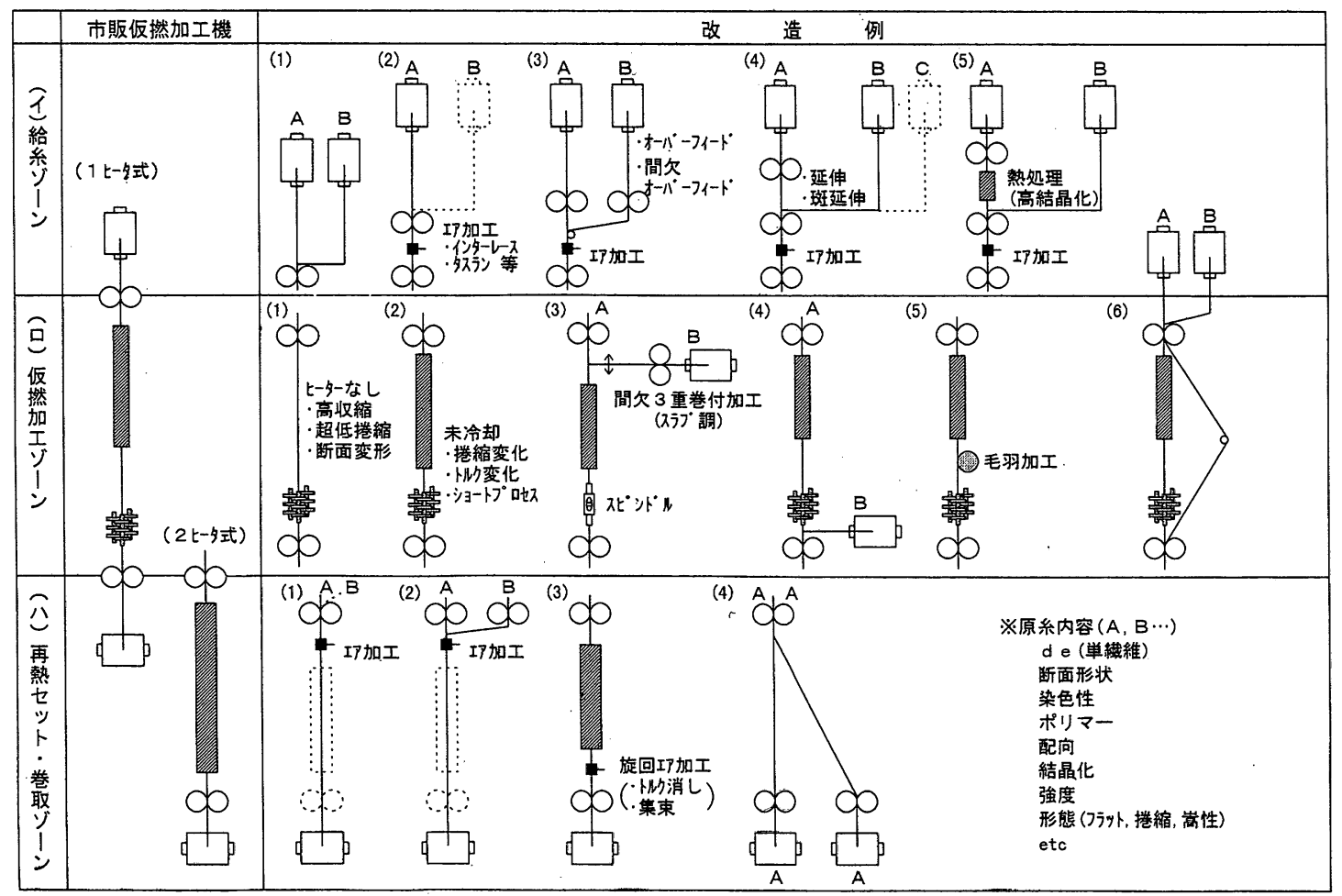

図 3 仮撚技術における特化プロセス(例) 


\begin{tabular}{|c|c|c|}
\hline 断面形 & 特徴 & 加工法 \\
\hline$(1) \stackrel{+}{\circ} \stackrel{+}{\infty}$ & $\begin{array}{l}\text { 断面変形大 } \\
\text { 断面変形防止 }\end{array}$ & $\begin{array}{l}\text { 延伸仮撚 } \\
\text { 高撚係数仮撚 } \\
\text { 低撚係数仮撚 } \\
\text { 低温仮撚 }\end{array}$ \\
\hline ( 3 ( ) & $\begin{array}{l}\text { ミックス構造 } \\
\text { 芯朝櫣造 } \\
\text { (スハフイス風合) }\end{array}$ & 複合仅撚 \\
\hline 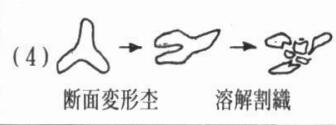 & $\begin{array}{l}7 \text { フフリル糒造 } \\
\text { (七ルロース風合) }\end{array}$ & 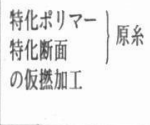 \\
\hline 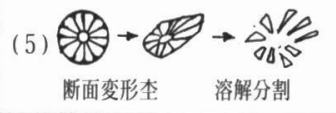 & 極細風合 & $\begin{array}{l}\text { 仮撚加工 } \\
\text { 低温仮撚加工 }\end{array}$ \\
\hline (6) & 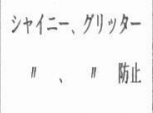 & $\begin{array}{l}\text { 凹凸 } \\
\text { スリット側面 } \\
\text { 原糸の仮撚加工 }\end{array}$ \\
\hline 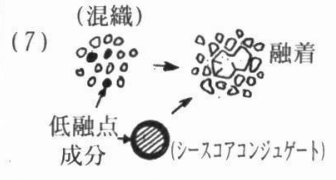 & $\begin{array}{l}\text { シャリ感 } \\
\text { リネンン調 } \\
\text { 丸味断面 }\end{array}$ & 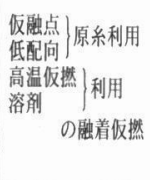 \\
\hline
\end{tabular}

図 5 各種仮撚加工条の断面形態

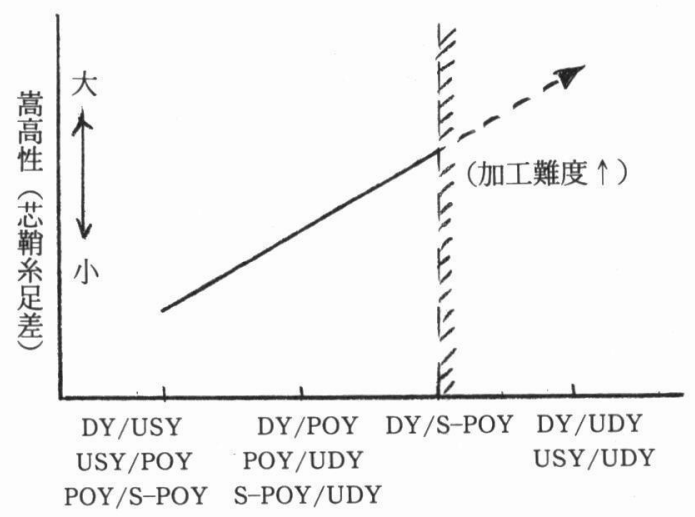

図 6 複合仮撚における複合原系の影響

どとの複合使用が可能になる。

（d）その他；上に述べた例はほんの一例で，原 系と加工プロセスおよび加工条件をうまく利用して やると, 風合い(嵩, 腰反発, ドレープ, 他), タッ チ（清涼〜ウォーム, ドライ〜スムース, 超ソフト 〜ハード, 他), 外観 (光沢, 色調, フィラメント〜 スパン, 均一〜不均一，凸凹，しば，他）などは,

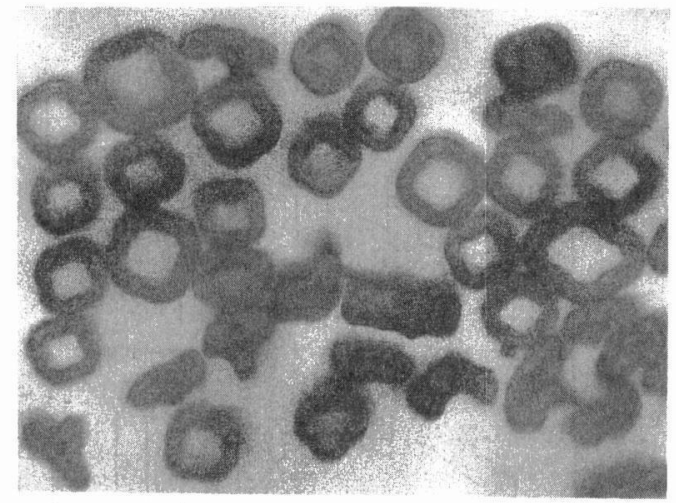

図 7 中空断面条例

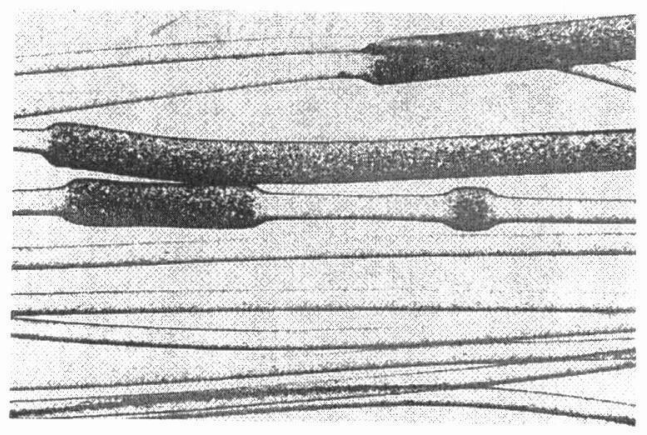

図 8 斑延伸系(例 ${ }^{8)}$

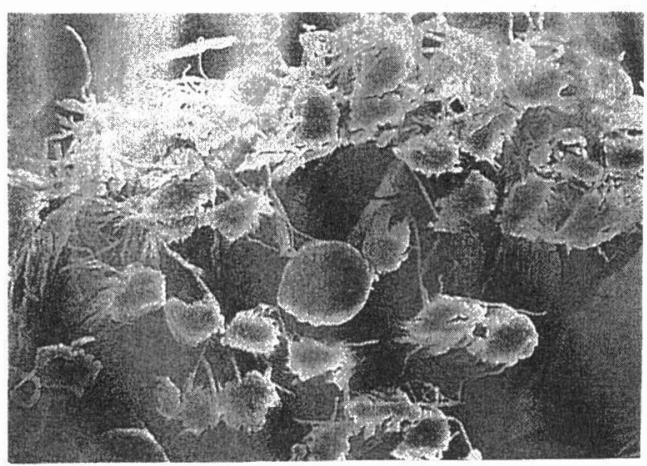

図 9 フィブリル繊維例 ${ }^{10)}$

かなり自由に調整できる他, コンジュゲート（S/ $\mathrm{S})$, 制電, 吸湿, 撥水等の原系を利用してやると, さらに機能性についても種々調整することができ る.

(2) ニューリネン

例えば，図 3(イ) (1) (2) (4)，(口) (3)等のプロセスを 利用し, 図 4(7) (7)等の糸構造に加工してやると, リネンの外観および風合いに近いものができるが, さらに, これに特殊異形断面や多孔あるいは多溝表 面改質ポリマー等の特化原系を適用し, さらに, ア 


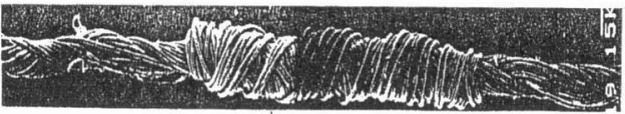

図10 間欠巻付仮撚条例 ${ }^{11)}$

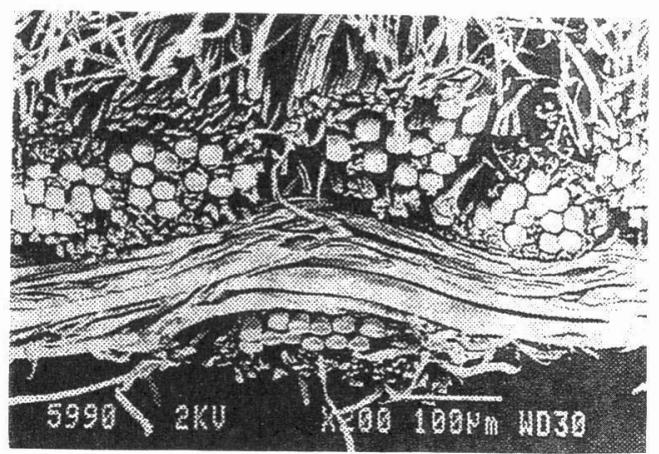

図11 人工皮革例 ${ }^{12}$

ルカリ減量, カレンダー加工，バフ加工等の染仕上 げ加工を併用してやると，感性の幅をさらに広げる ことができる.

また, 図 4(11)のスラブパターンも, 図3(3)プロセス における B 原糸の供給方法によりピッチ, 太細比な どは自由に選定できる他, 供給原糸の種類により, 表情あいろいろ変えることが可能である（図10参照 )$^{11)}$.

\section{(3) 薄起毛}

例えば，図 3(イ) (2) (3) (4), (口) (1) (5) (6), (y) (1)等 のプロセスを利用し，図 4(8) (13), 図 5(3) (4) (5)等の 糸構造に加工する際，鞘系成分に極細繊維あるいは 割繊性特殊異形断面繊維またはフィブリル繊維等を 利用してやると極細繊維やフィブリル等による薄起 毛調風合いを付与することができる.

さらに，ここで，図3(ロ) (1) (6)等のプロセス，あ るいは高収綿原糸等を利用したりして収縮特性を大 幅に upしてやると, 布帛の充填密度が高度に緻密 化し，スエードやヌバックといった高級皮革調の風 合い並びに外観も付与することができる（図11参 照 ${ }^{12)}$ ).

なお,ここでも, 原糸, 糸加工以外にやはり織編 染加工に至るまでの細心の技術 KNOW-HOW が必 要になる.

\section{2 エアジェット加工技術}

本技術には, (i)(1)混繊加工 (インターレース), (ii)

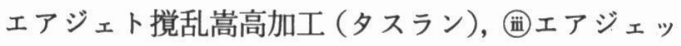
卜押し込み加工 (エアスタッフ), (ivエアジェット衝 突加工等の技術が含まれるが, 今日よく利用されて いるのは，主に(i混緎加工技術である。

すなわち, 熱収縮率の異なる複数の原糸をエアジ エットノズルでミックスし, 染色工程でこの収縮差 を発現させ，これによって布帛にふくらみを付与す るという技術で，すでに約 35 年位の歴史を持ってい る.

仮撚加工の場合と違って, 織維断面に変形を伴わ ないため，三角断面等の光沢を維持したままふくら みが付与できるということで, 主にシルキー調素材 の加工に利用されてきた．初期の頃は，熱セットの 有無あるいは異素材のミックスなどで高々 10 パーセ ント前後の収縮差であったが, 熱セットの強化ある いは高収縮特性の得られる特殊延伸技術が用いられ るようになると，これが20パーセント前後にまで拡 大し, 昨今は自己伸張特性あるいは超高収縮ポリマ 一の利用などにより，これがさらに 30 パーセント前 後にまで拡大し, 天然のシルクよりはるかにバルキ 一なシルキー素材材, いわゆる新合繊6)が開発され ている.

一方，設備的には，当初フィラメントの延伸機が 流用されていたが，前述の仮撚加工機の場合と同様 に，これにもいろいろな工夫が凝らされるようにな り，図12に示すようなさまざまな改良プロセスが工 夫されている ${ }^{13)}$.

図13は，その改良プロセスによって造り出された 混繊系の構造をモデル的に示したものである. 前述 の仮撚加工技術の場合と同様，これらに原糸の種類 と加工条件を掛け合せるすと, やはり膨大な種類の 特化混繊糸ができ，ニューシルキー分野以外にもレ ーヨン・ドライ分野, 薄起毛分野など, 今日の新合 繊に巾広く利用されている.

また, 最近は繊維機械メーカーからあこの手の加 工機が市販されており，特許に低触さえしなければ 誰でも造ることができる(図14参照) ${ }^{14)}$.

なお，混繊系は単純な収縮差構造を取るため，一 般に均一で単調な外観になりやすいが，延伸する際 に斑を入れたりすると染着差や収縮差がプラスさ れ，外観をナチュラルにすることができる（㘰15参 照 $\left.{ }^{15)}\right)$. これまでに斑を出すいろいろな延伸および熱 処理技術が開発され，図16に示すような様々な斑パ ターンが自由に得られるようになっており，上記の 混繊糸構造や特化原糸との組み合わせにより天然緎 維に近いナチュラル感が得られるようになってきて いる.

ただ,これらの混繊糸は, 高伸度, 高収縮, 染着 


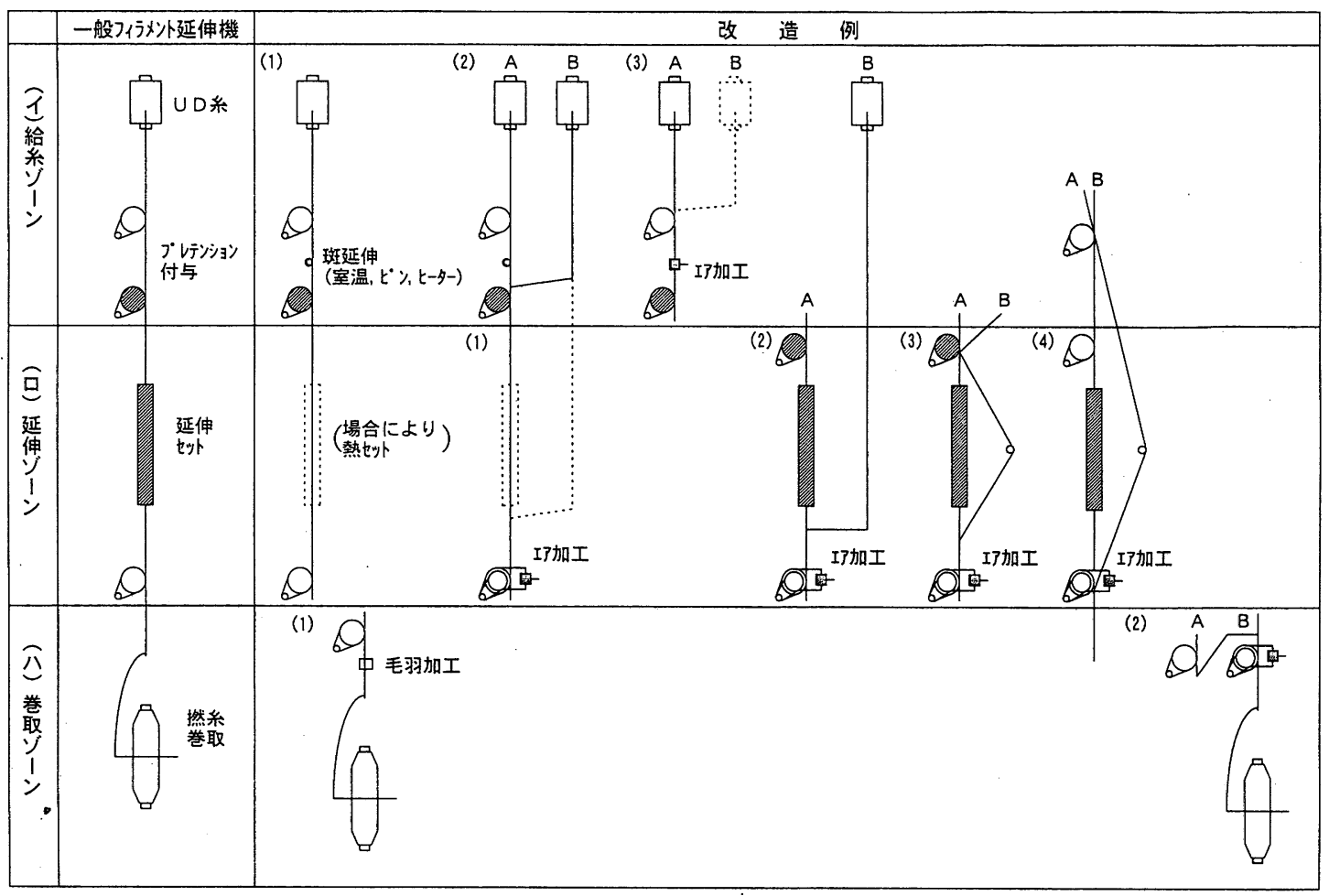

図12 混織技術における特化プロセス例13)

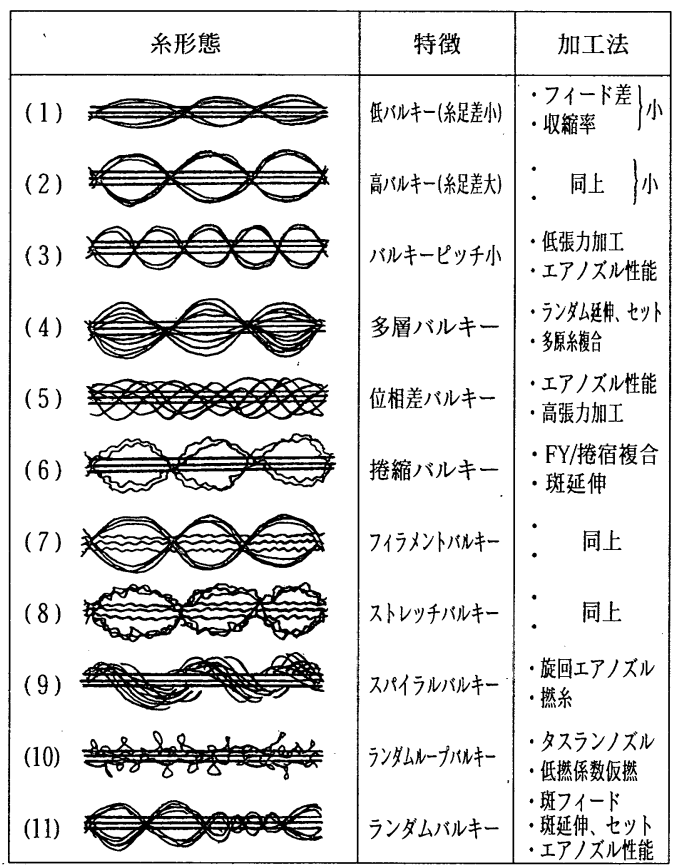

図13 各種湿織糸の条形態

差, 単純ループ嵩性など, その加工原理から生じる 本質的な特性を有するため, 後工程での取り扱い, 製品の実用特性などの面でやはり細心の注意が必要 である.

\section{3. 糸加工技術の今後の方向}

前述の内容から推測されるように，仮撚加工およ び混繊加工技術はすでに成熟化しており，昨今の新 合織も, 加工プロセスよりむしろ特化原糸の活用に よって生まれたと推定されるあのが多い.

また，その新合緎(6) こここ10年位の間に約 300 件 あ上市され, 質は向上しているものの差別化効果は かなり低下してきているようにみえる.

従って, 今後の糸加工技術としては, 表 2 に示す ような(1)現状技術のコストダウン並びに(2)次世代高 付加価値技術の創出等が重要なポイントになるもの と推測される.

ただ表 2 のうち，(1-i)，ii）についてはすでにか なり進行しており，例えば，図1 $17^{16)}$ のように紡糸工 程だけで製品を得たり，図 $18^{17)}$ のように異収縮原糸 あるいは異伸度原糸を紡系段階で複合してしまうよ うな合理化技術が種々開発されつつある。 また，(1) 


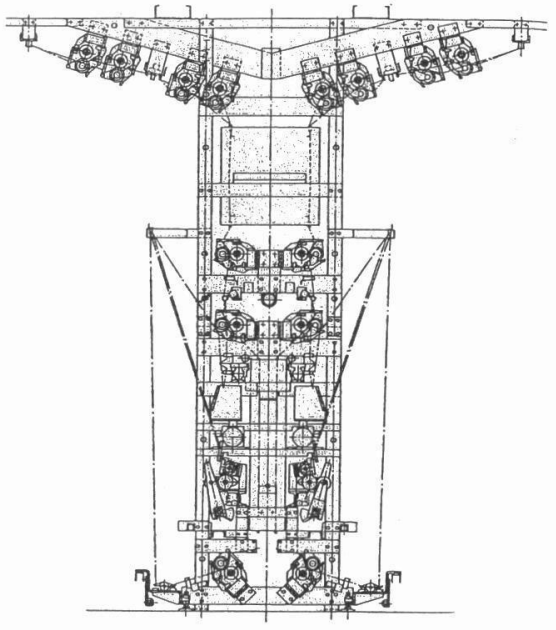

(1) 愛機製作所 $\ulcorner A T-501 E X ~ I I ~\lrcorner^{(4)}$

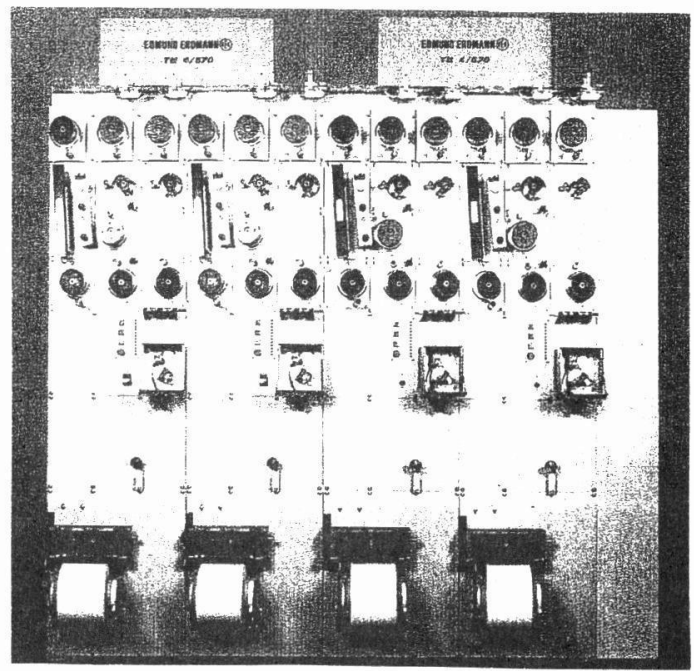

(2) EDMUND RDMANN 「TEXMOD8/570 $\lrcorner^{14)}$ 図14 最新エアジェット加工機例

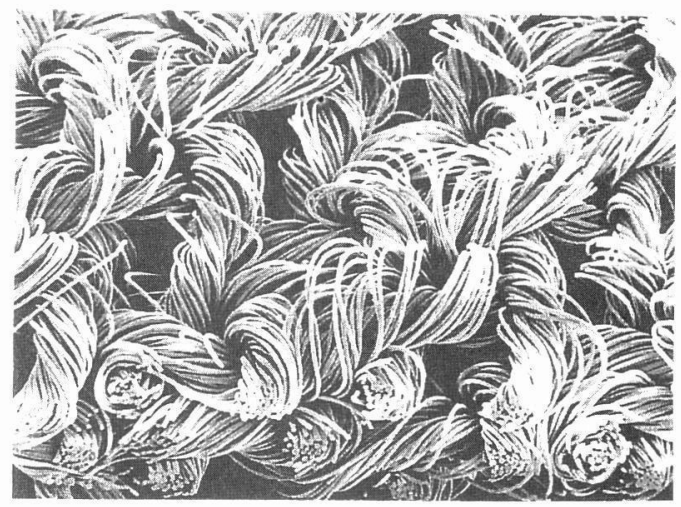

図15 ナチュラル混㵶条(例 ${ }^{15)}$

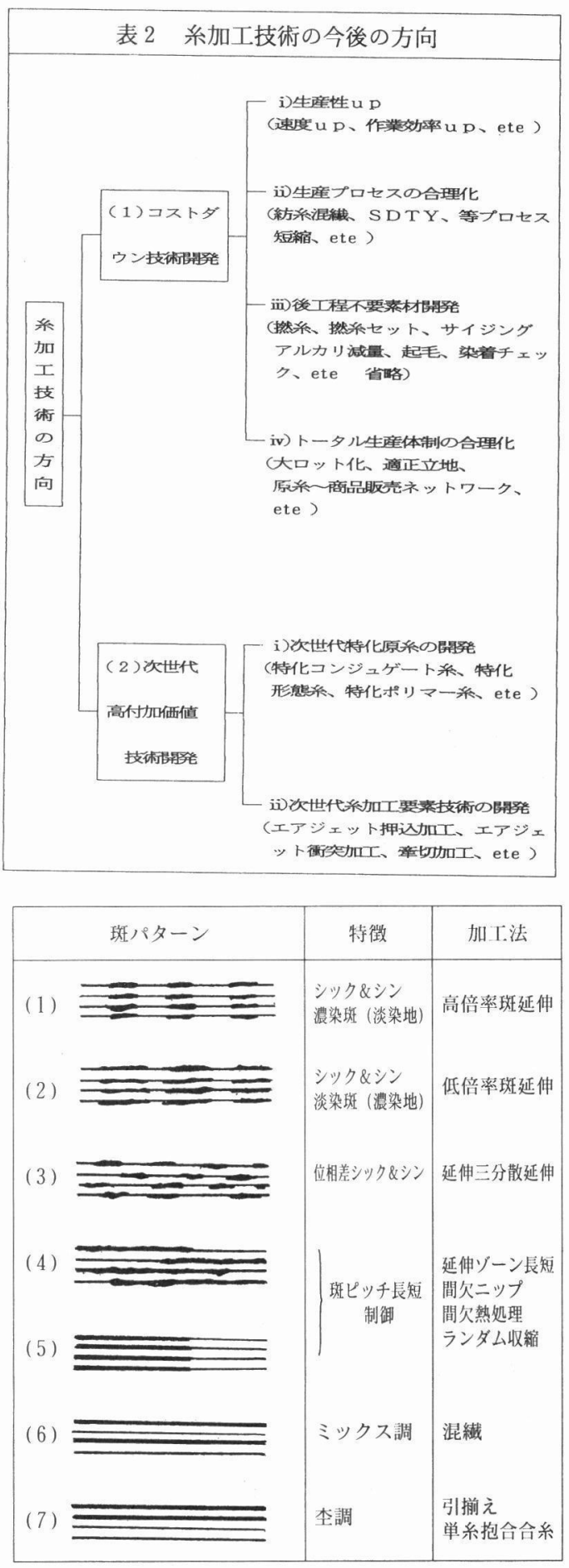

図16 各種斑延伸による斑パ夕ーン

-iii）iv）については, 今のところあまり目立った進 展が見られないが，例えば，織物コストを見ても， 織染コストの方が糸より高く付いており，その分合 


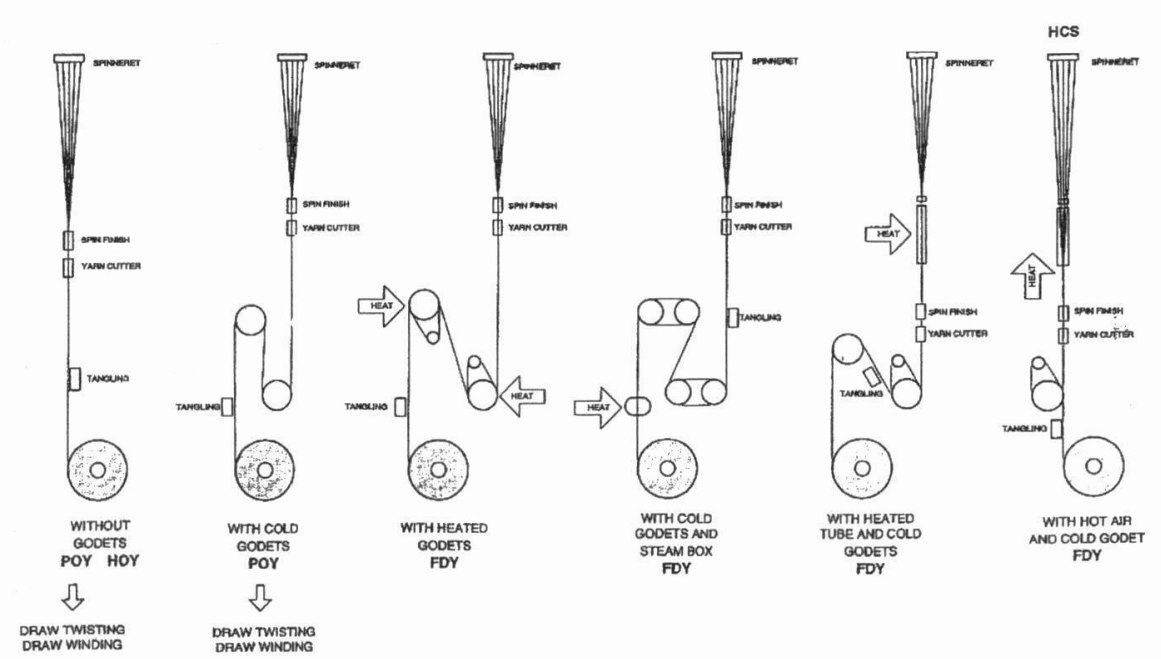

図17 各種革新紡糸技術例 ${ }^{16)}$

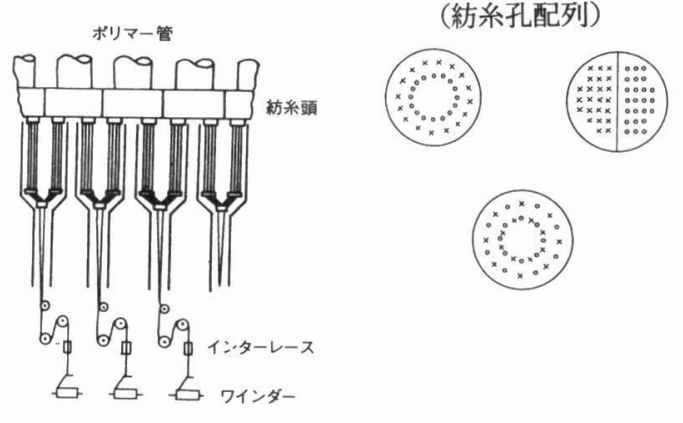

図18 紡糸混繊維技術例 ${ }^{17}$

理化効果む狙えるわけで, 近いうちに検討しなけれ ばならない課題である。

一方，(2)-i）については，すでにかなりの特化原 糸が存在し,さらに種類を増すことは(1)-iv) の大口 ット化と相反することになるが，コンジュゲート技 術などは未だポテンシャルが十分あると考えられ注 目される (図19参照 ${ }^{18)}$ )。 また, (2)-ii) については, 成功すればその波及効果は莫大であるが, 仮撚加工 と混瀻加工以外の新技術が長い間育たなかったこと からして簡単ではなさそうである.

ただ，(1)-ii）対応としての仮撚加工技術について 考えると, 現行の撚掛け技術は紡系工程との連結が 難しく, 別の捲縮手段が必要になると思われるが, その候補技術屯兼称てエアジェット押込加工技術 (図20(1)参照 ${ }^{19)}$ やアジェット衝突加工技術などは, 次世代加工技術として注目される.すなわち, 加熱 エアの取り扱いなど難しい面もあるが高速加工に向 いており, 特に前者は自ら熱収縮を一定に保つセル

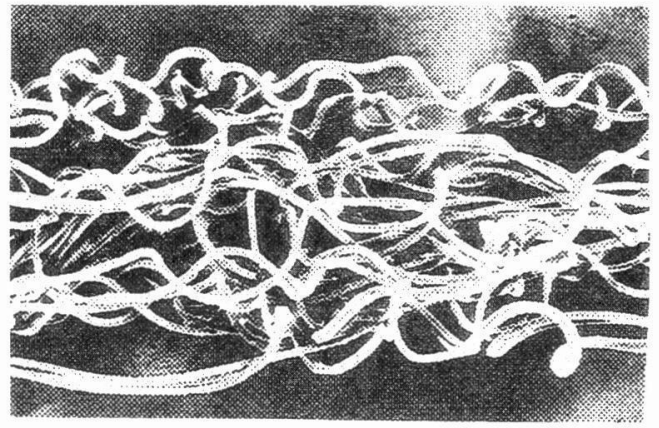

図19 ランダム捲縮コンジュゲート条例 ${ }^{18)}$

フコントロール機能を有していたりして興味深い.

また, あまり一般的な技術ではないが, 牽切加工 技術 ${ }^{20)}$ む, 次世代加工技術としては注目に值する (図 20(2)参照 ${ }^{21)}$ )。すなわち, 牽切メカニズムから生 まれる独自の感性は, 従来の加工技術と差別化する 上で大きな武器になる他，(1)-ii) 等で得られる原系 などと組み合わせると, 加工ポテンシャルあ商品ポ テンシャルもかなり期待でき, 興味深い. ただ, フ ィラメントのスパナイズ加工糸とはいえ当然のこと ながら，スパン用設備で扱う必要がある.

\section{4. おわりに}

グローバル市場で競争に勝っていくためには, ど こよりあ良い商品をどこよりあ安くかつクイックリ 一に消費者に提供できなければならない.

そのためには, 素材メーカーから小売りに至る関 連企業が各々に対応するよりあ，ネットワーク化な どを通して一体化し，素材から小売りに至るトー夕 


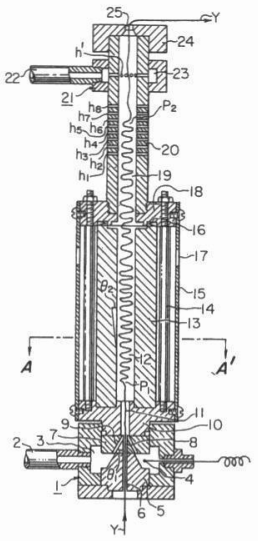

(1) エアジェット押込技術例19)

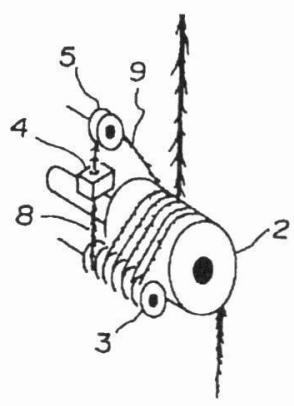

(2) 牽切加工技術例 ${ }^{21)}$

図20 次世代糸加工要素技術例

ルコストを考えた戦略的コスト配分ができるように なるのが理想的である.

すなわち，手前味噌になるが，素材への投資効果 を考えた場合, 商品価格に占める素材コストの比率

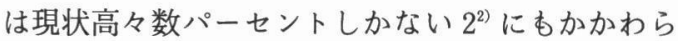
ず, 商品偏値に占める素材の貢献度はその比ではな いほど大きく，戦䀩的に素材にコストを配分するメ リットは十分あると思われる。

幸い日本には先に述べた先進の素材技術が充実し ており, どこよりあ良い商品を提供していける強味 がある.

しかし，一方，ついコスト合理化に偏重し，質を 疎かにしたりすると，2000年にはポリエステル緘維 の供給過剩問題が控えており, 泥沼に引き込まれる 危険性む十分予想される.グローバリゼーションの 結果として, 日本が世界における最先端瀻維技術と ファッションの発信基地になっていて欲しいもので ある.

\section{引用文献}

1）帝人製機「HTS-15V」パンフレット

2) 村田機械 $\ulcorner$ Mach Crimper No. 33H」パンフレット

3）繊維学会誌；繊維と工業, 50, No. 6 (1994)

4）䋐維学会,「新しい衣料材料の普及展示講演会」要旨集 織維社「複合素材の実際知識」

引用文献 1）参照

引用文献 2）参照

5）引用文献 4）参照

6) 繊維学会誌 ; 織維と工業, 48, No. 7 (1992), International Man-Made Fibers Congress19-21, Sept. 1990, No. 29, $\ulcorner$ Recent Developments of PES-Fibers for Apparel and Future Directions」

7）織維学会誌；繊維と工業, 50, No. 6 (1994)

8）瀻維学会,「緘維便覧」

9）緘維学会,「最新の織維技術レビュー講演会」要旨集

10）縥研新聞広告, 三菱レ「WAY 引用文献 9）参照

11）繊維学会,「織維便覧」

12）帝人「レネッサ」TEIJIN TECHNOLOGY REPORT VII, 1996

13）織維社, 複合素材の実際知識, 村田機械 $\ulcorner 23$ 加工機-No. 35 $\mathrm{A}\lrcorner$ パンフレット

14）愛機製作所「AT-501 EX-II」パンフレット, Dec. 1996

15）帝人「ガーディア』

16) MAN-MADE FIBER YEAR BOOK Sep. 1996

17）緎維機械学会, 織維工学 II

18）鐘紡「オペラ®」

19) USP 4188691

20）緘維機械学会誌，織維工学, 45, No. 12 (1992)

21) 特開平 $5-5225$

22）織研新聞，'95 11月28日

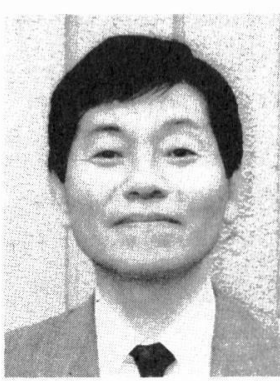

松本 三男（まつあとみつお） 昭和 43 年群馬大学工学部卒, 現 在, 帝人(侏加工技術第 1 部新素材グ ループに所属. 糸加工を主体とした 新素材, 新商品開発業務に従事.（帝 人(㑣)加工技術第 1 部， = 567-0006 茨木市耳原 3-4-1，TEL。 0726-431043, FAX. 0726-43-1032) 